\title{
The complex vocalization of Scinax cardosoi (Anura: Hylidae), with comments on advertisement calls in the $S$. ruber Clade
}

\author{
Thiago Ribeiro de Carvalho ${ }^{1,2}$, Lucas Borges Martins ${ }^{1,2}$, and Ariovaldo Antonio Giaretta ${ }^{1}$ \\ ${ }^{1}$ Laboratório de Taxonomia, Sistemática e Ecologia Comportamental de Anuros Neotropicais, Faculdade de Ciências Integradas \\ do Pontal, Universidade Federal de Uberlândia (UFU), Rua 20, 1600, 38304-402, Ituiutaba, Minas Gerais, Brazil. \\ E-mail: thiago_decarvalho@yahoo.com.br. \\ ${ }^{2}$ Programa de Pós-Graduação em Biologia Comparada, Departamento de Biologia/FFCLRP, Universidade de São Paulo, \\ Avenida dos Bandeirantes, 3900, 14040-901, Ribeirão Preto, São Paulo, Brazil.
}

\begin{abstract}
The complex vocalization of Scinax cardosoi (Anura: Hylidae), with comments on advertisement calls in the $S$. ruber Clade. The complex vocalization of Scinax cardosoi from a population of Minas Gerais in southeastern Brazil is described and compared with available acoustic data for the other species of the $S$. ruber Clade. Three distinct types of high-pitched, pulsed calls were identified, and are referred to as "short," "long," and "trilled" calls. Short calls (16-66 ms) resemble squeaks, and consist of a pulsed signal (8-28 pulses/call) with regular amplitude modulations throughout their duration; the amplitude peak occurs at about the midpoint of the call duration. Long calls (268-518 ms) resemble giggles, and have lower amplitude than short calls; typically, they consist of pulsed note series (1-6 notes/call). Trilled calls resemble insect chirps and have the lowest amplitude of the three call types; they consist of long (1.1-3.0 s) pulsed note series (9-25 notes/call). Acoustic data are taxonomically informative in the Scinax ruber Clade and provide phenotypic characters diagnosing $S$. cardosoi in addition to those features proposed in its original description. The vocalization repertoire of $S$. cardosoi resembles the complex vocal repertoires (i.e., multiple call types emitted in variable combinations) of members of the $S$. catharinae Clade more than some species of the $S$. ruber Clade, which tend to have simpler call structures (i.e., a single type of multipulsed note).
\end{abstract}

Keywords: acoustic repertoire, amphibians, call functions, Minas Gerais state, southeastern Brazil. 


\begin{abstract}
Resumo
A vocalização complexa de Scinax cardosoi (Anura: Hylidae), com comentários sobre cantos de anúncio no Clado de $S$. ruber. A vocalização complexa de Scinax cardosoi de uma população do estado de Minas Gerais no sudeste brasileiro é descrita e comparada com os dados acústicos disponíveis para outras espécies do Clado de $S$. ruber. Três tipos diferentes de cantos pulsados e agudos foram identificados, denominados cantos "curto," "longo" e "trinado". Cantos curtos (16-66 $\mathrm{ms}$ ) lembram chios e consistem em sinais pulsados (8-28 pulsos/canto) com modulações de amplitude regulares ao longo de sua duração e pico de amplitude aproximadamente na metade de sua duração. Cantos longos (268-518 ms) lembram risadinhas e têm menor amplitude quando comparados a cantos curtos; tipicamente, consistem em séries de notas pulsadas (1-6 notas/canto). Cantos trinados lembram zunidos de insetos e apresentam a menor amplitude dentre os três tipos de cantos; consistem em séries muito longas (1,1-3,0 s) de notas pulsadas (9-25 notas/canto). Dados acústicos são taxonomicamente informativos no Clado de $S$. ruber, fornecendo evidências fenotípicas à diagnose de $S$. cardosoi além das características propostas em sua descrição original. O repertório vocal de $S$. cardosoi assemelha-se mais aos repertórios vocais complexos (vários tipos de cantos emitidos em combinações variadas) de espécies do Clado de $S$. catharinae do que ao de algumas espécies do Clado de $S$. ruber, os quais tendem a ter uma estrutura do canto mais simples (um tipo único de nota multipulsionada).
\end{abstract}

Palavras-chave: anfíbios, funções do canto, Minas Gerais, repertório acústico, sudeste do Brasil.

\section{Introduction}

Anuran vocalizations can contribute to the resolution of taxonomic issues-e.g., revealing cryptic diversity (Heyer et al. 1996, Carvalho and Giaretta 2013) — and the determination of identities of species with variable or poorly known phenotypic characters (Padial et al. 2008). They also are useful in detecting macroevolutionary patterns (Cocroft and Ryan 1995, Robillard et al. 2006), as well as in conducting biodiversity inventories or monitoring frogs in visually inaccessible habitats (Obrist et al. 2010).

Scinax currently comprises 113 species distributed from eastern and southern Mexico, Central America, and throughout South America to Argentina and Uruguay (Frost 2015). Faivovich (2002) proposed two major clades in the genus-the $S$. catharinae and the $S$. ruber clades - both of which were corroborated by Faivovich et al. (2005) with a larger taxon sampling. Two species groups are recognized in the $S$. ruber Clade- the $S$. rostratus and the $S$. uruguayus groups; several other species remain unassigned to either of the species groups (Faivovich et al. 2005). Vocalizations (particularly advertisement calls) have supplemented species-level diagnoses in Scinax (De la Riva 1993, Nunes et al. 2012).

Scinax cardosoi (Carvalho-e-Silva and Peixoto 1991) was described from Teresópolis (Rio de Janeiro state) and Domingos Martins (Espírito Santo state), southeastern Brazil, and is assigned to the $S$. ruber Clade (sensu Faivovich et al. 2005). The species recently has been reported from three municipalities of Minas Gerais state in southeastern Brazil (Pinto et al. 2009, Linares et al. 2011), but its vocalization has not been described to date.

Herein, the vocalization of Scinax cardosoi is described from a population near $(\sim 45 \mathrm{~km})$ its type locality (Teresópolis, Rio de Janeiro) in Minas Gerais. The vocalization is compared to published reports of advertisement calls for the other species of the $S$. ruber Clade that are not assigned to a species group. 


\section{Materials and Methods}

Fieldwork was conducted from 30 November-4 December 2011 in the Municipality of Chiador $\left(21^{\circ} 55^{\prime} \mathrm{S}, 42^{\circ} 51^{\prime} \mathrm{W}\right)$, Minas Gerais state in southeastern Brazil; this locality is fewer than $50 \mathrm{~km}$ north of the type locality of S. cardosoi (Teresópolis, Rio de Janeiro state). Voucher specimens (ICMBio/SISBIO permit \# 30059) are housed in the Collection of Amphibians of the Museu de Biodiversidade do Cerrado at the Universidade Federal de Uberlândia (AAG-UFU) under the following accession numbers: AAG-UFU 0681-0687; all specimens but the female AAG-UFU 0681 are call vouchers.

Comparisons of morphological, morphometric, and coloration characters are based on those of the original description of $S$. cardosoi (Carvalho-e-Silva and Peixoto 1991). Snoutvent length $(\mathrm{SVL})$ was measured with calipers to the nearest $0.05 \mathrm{~mm}$ following the methodology of Duellman (1970). Calls of six males were recorded using a Sennheiser K6/ME66 directional microphone (positioned approximately $1 \mathrm{~m}$ from calling males) and a M-Audio MicrotrackII digital recorder set at a sampling rate of 48 $\mathrm{kHz}$ and a resolution of 16 bits. Air and water temperatures were measured with a digital thermometer after vocalizations were recorded for 1-2-min. Calls were analyzed with the software Raven Pro 32-bit 1.5 Beta version (Bioacoustics Research Program 2012). Temporal traits were measured from oscillograms; the dominant frequency was obtained through "Peak Frequency" measurement function. Raven Pro settings: window size $=256$ samples; window type $=$ Hann; $3 \mathrm{~dB}$ filter bandwidth $=$ $270 \mathrm{~Hz}$; overlap $=85 \%$; hop size $=0.79 \mathrm{~ms}$; DFT size $=1024$ samples; grid spacing $=46.9$ $\mathrm{Hz}$. Sound figures were generated with Seewave package version 1.7.3 (Sueur et al. 2008), R platform version 3.1.0 (R Core Team 2014), with the following settings: window type $=$ Hann; window length $=128$ samples $($ FFT); overlap $=85 \%$.
Acoustic terminology follows that of Carvalho et al. (2015). We realize that the functions of calls cannot be classified without being investigated in a behavioral/experimental framework. Our categorizations of calls are based on information that could be gathered in the field while recording $S$. cardosoi vocalizations; we consider these a practical way to facilitate interspecific comparisons. Our assignment of calls to vocalization categories follows the suggested nomenclature proposed by Toledo et al. (2015). The rarest call (hereinafter "trilled" call) was recorded from only one isolated male and it might be considered in a reproductive context; if so, the trilled call probably is either the advertisement call or at least the major advertisement signal. The other two call types (hereinafter "short" and "long" calls) usually were emitted either as single calls or intermingled with one another in phrases. These seem to have reproductive significance in signaling the position of one male to the nearest conspecific male (recognized function for advertisement calls; Gerhardt 1994). Additionally, the short and long calls may figure in aggressive behavior between conspecific males because neighboring calling males were observed to broadcast phrases of these two call types at high rates (aggressive call definition fide Wells 2007). Thus, different call types may convey different messages to males and females, respectively (Narins and Capranica 1978).

The species compositions of clades and species groups of Scinax are those of Faivovich (2002) and Faivovich et al. (2005). Bilate and Lack (2011) summarized advertisement call traits for several species of the $S$. ruber Clade. These authors proposed a straightforward classification of calls based on their duration-i.e., short (up to $\sim 350 \mathrm{~ms}$ ) and long (> $350 \mathrm{~ms}$ ) calls, which we adopt to facilitate interspecific comparisons. Acoustic comparisons include only the unassigned species of the $S$. ruber Clade (i.e., all species except those in $S$. rostratus and $S$. uruguayus groups). 


\section{Results}

Our specimens match the original diagnosis of Scinax cardosoi by Carvalho-e-Silva and Peixoto (1991), as follow. (1) Adult males small (SVL 18.7-19.9 mm, mean $=19.4 ; N=6)$; female larger (SVL $24.4 \mathrm{~mm} ; N=1$ ). (2) Upper shank surfaces with oblique bars (Figure 1A). (3) A broad, longitudinal stripe extending from eye to inguinal region; a thin, occasionally fragmented vertebral stripe (Figure 1A). (4) Ventral surfaces (throat, forearms, shanks, and flanks) with distinctive dark-colored mottled pattern (Figure 1B). (5) Lateral aspect of head acuminate.

Male Scinax cardosoi were observed to call from perches $0.5-1.0 \mathrm{~m}$ above the ground on grassy vegetation in temporary, rock-bottomed pools near forest borders and in clearings. Bokermannohyla circumdata and S. hayii were also in calling activity at the locality. Three distinct types of high-pitched, pulsed calls were identified (Table 1; Figures 2-4), herein referred to as "short," "long," and "trilled" calls. Short calls (Figure 2B) resemble squeaks and consist of a pulsed signal with regular amplitude modulations throughout their duration, and have amplitude peak about midway during the call duration. This call type was emitted by all six males $(N=73$ calls $)$, at highly variable rates, ranging from 3.1-57.1 calls $/ \mathrm{min}$ (mean $=17.0$, $\mathrm{SD}=20.1)$. Short call duration varies from 1666 ms (mean $=40.0, \mathrm{SD}=8.1$ ), with intervals from 0.5-11.9 s (mean = 5.8, $\mathrm{SD}=4.6)$. Almost all short calls are emitted as single notes, but two males $(N=4$ series) emitted two-note series (Figure 3A). In all two-note series, the second note has fewer pulses and a shorter duration. In the cases of two-note series, intervals between notes are shorter, varying from 5-87 $\mathrm{ms}$ (mean = 63.0, SD = 28.6). Short calls have 8-28 pulses (mean $=20.6, \mathrm{SD}=2.9)$ and are emitted at high rates varying from 340.0-678.6 pulses/s (mean = 525.1, $\mathrm{SD}=90.8)$. The dominant frequency varies from $3281-4828 \mathrm{~Hz}$ (mean $=4429.1, \mathrm{SD}$ =91.9).
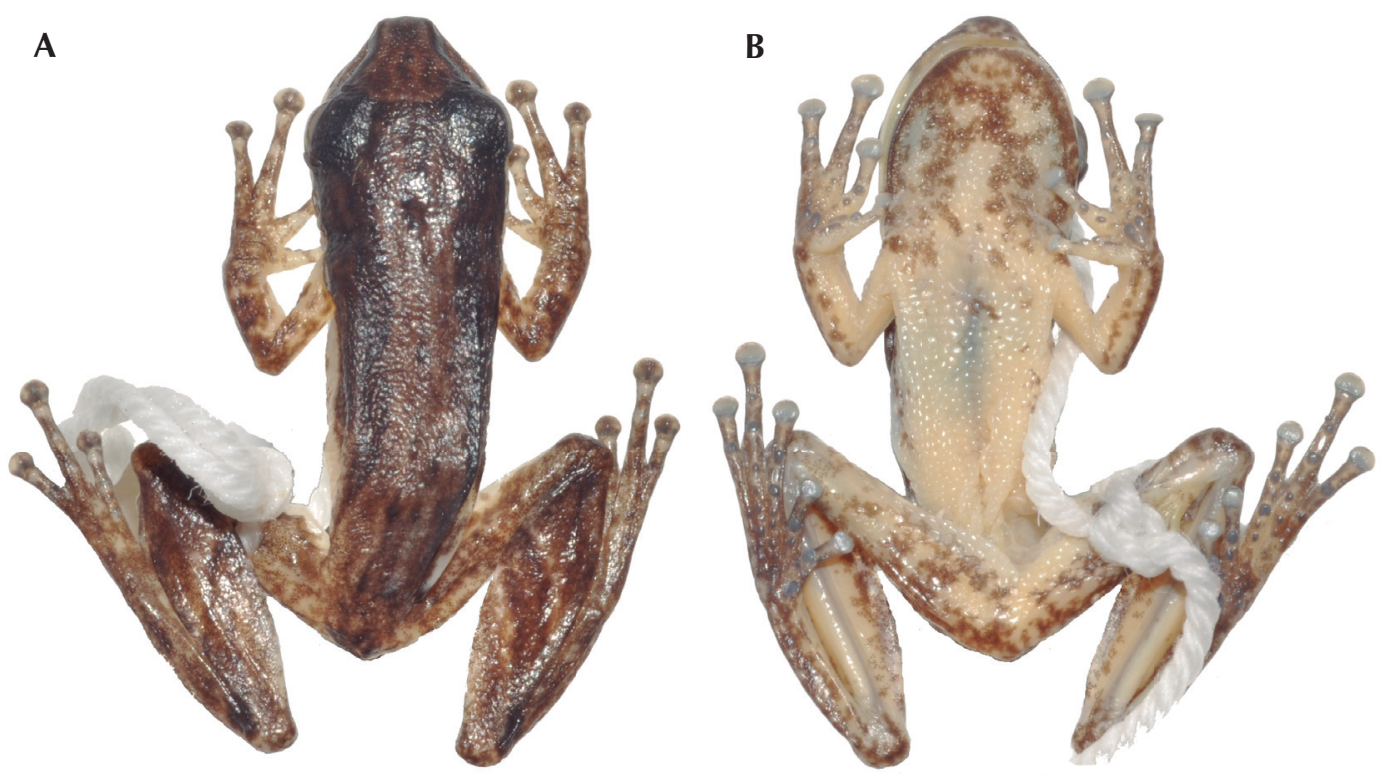

Figure 1. Dorsal (A) and ventral (B) views of the adult male AAG-UFU 0682 (SVL: $18.7 \mathrm{~mm}$ ) of Scinax cardosoi, collected in Chiador, Minas Gerais state, southeastern Brazil. 
Long calls (Figure 2C) were emitted by only three males $(N=14$ calls $)$ and have a lower amplitude than do the short calls; some portions of the long calls have ill-defined amplitude modulations, typically consisting of pulsed note series, resembling giggles. Long calls are highly variable in temporal traits (especially call interval and rate, pulse number, grouping, and spacing), and are emitted at highly variable rates, ranging from 2.0-37.2 calls $/ \mathrm{min}$ ( mean $=15.5, \mathrm{SD}=$ 19.0 ). They vary from $268-518 \mathrm{~ms}$ (mean = 427.0, $\mathrm{SD}=80.2$ ) and have $31-68$ pulses (mean

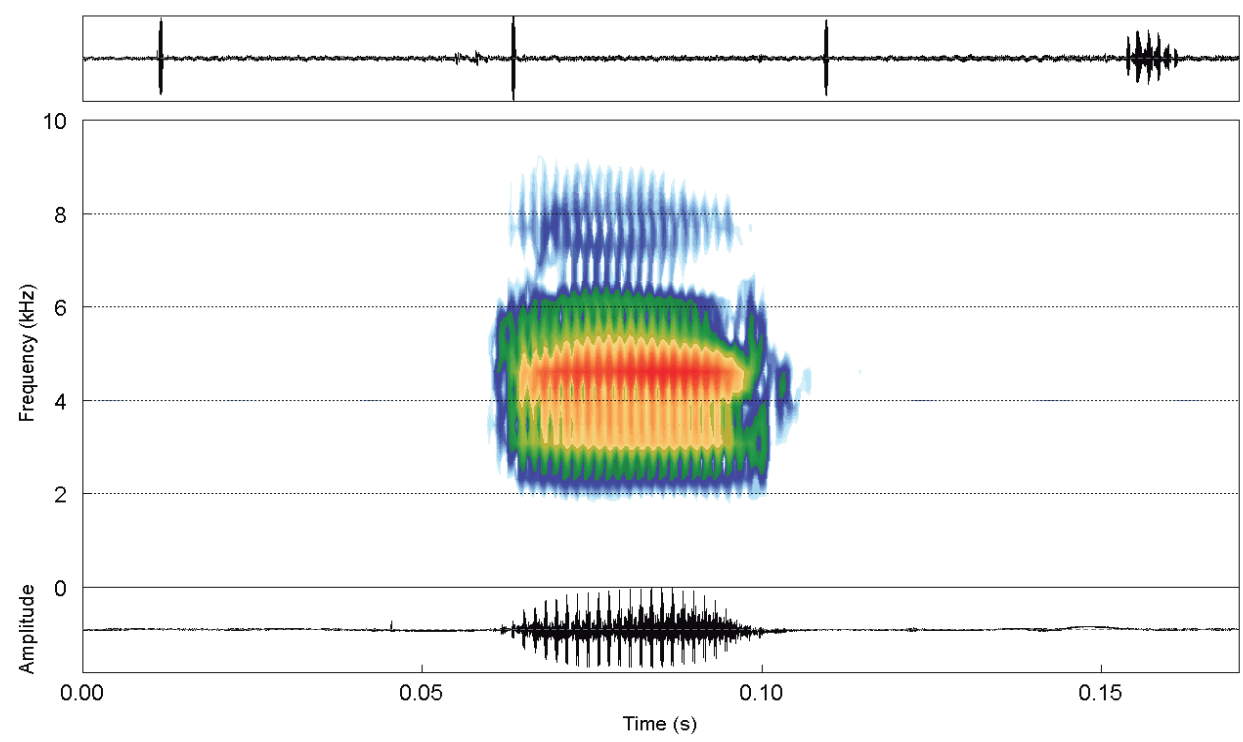

A

Amplitude

(dB)

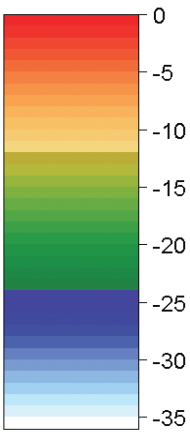

B

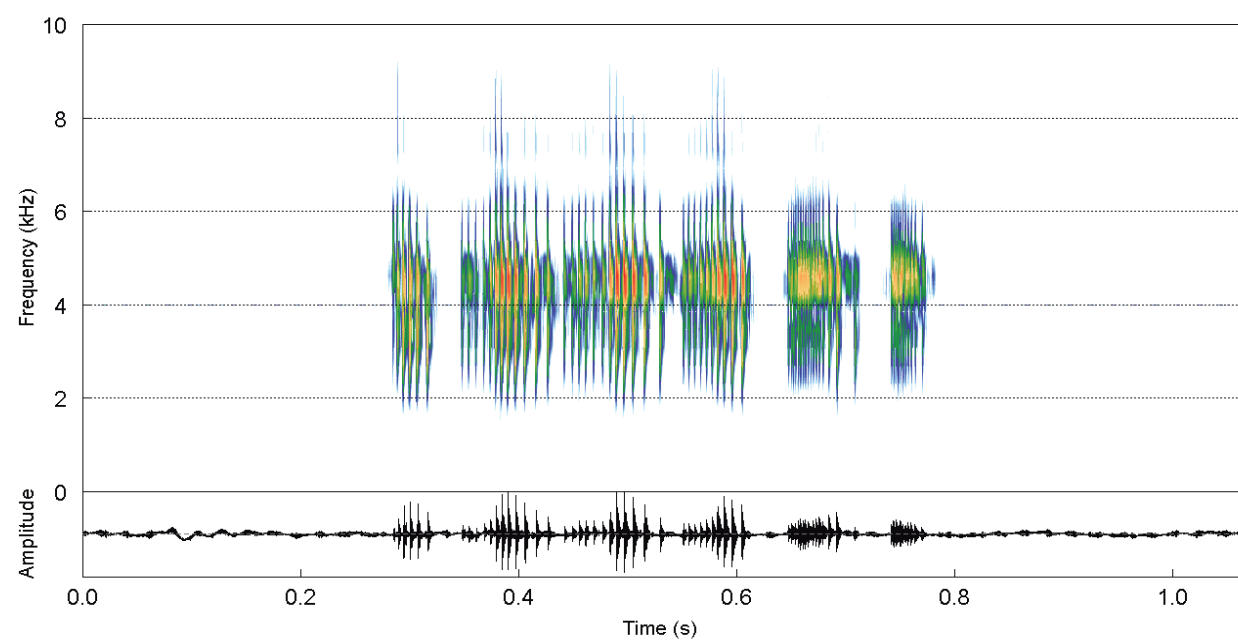

Amplitude

(dB)

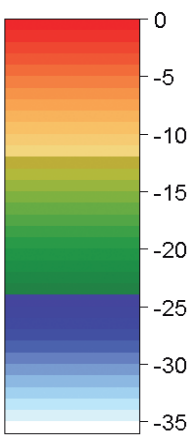

C

Figure 2. Short and long calls of Scinax cardosoi. Waveform (A) of a series ( 11 s) of three short calls followed by one long call; (B) spectrogram and respective oscillogram of the first short call in $A$; $(\mathbf{C})$ spectrogram and respective oscillogram of the long call in A. Sound file: Scinax_cardosoiChiadorMG2LBM_AAGmt; recorded at 00:20 h, on 3 December 2011; air $16^{\circ} \mathrm{C}$, water $19^{\circ} \mathrm{C}$. Recorded in Chiador, Minas Gerais state, southeastern Brazil. 
$=52.7, \mathrm{SD}=12.6)$ emitted at rates ranging from 78.5-147.6 pulses/s $($ mean $=124.4, \mathrm{SD}=9.7)$. In contrast to short calls, which almost always are emitted as single notes, long calls typically occur in series (Figure 2C), but one long call was emitted as a single note (Figure 3B). Long calls are formed by $1-6$ notes $($ mean $=3.7, \mathrm{SD}=$ 1.3). The dominant frequency varies from 4266$4500 \mathrm{~Hz}$ (mean = 4386.1, $\mathrm{SD}=34.8$ ).

Short and long calls were emitted in complex phrases at high rates in one recording, but in most cases, long calls were emitted at irregular

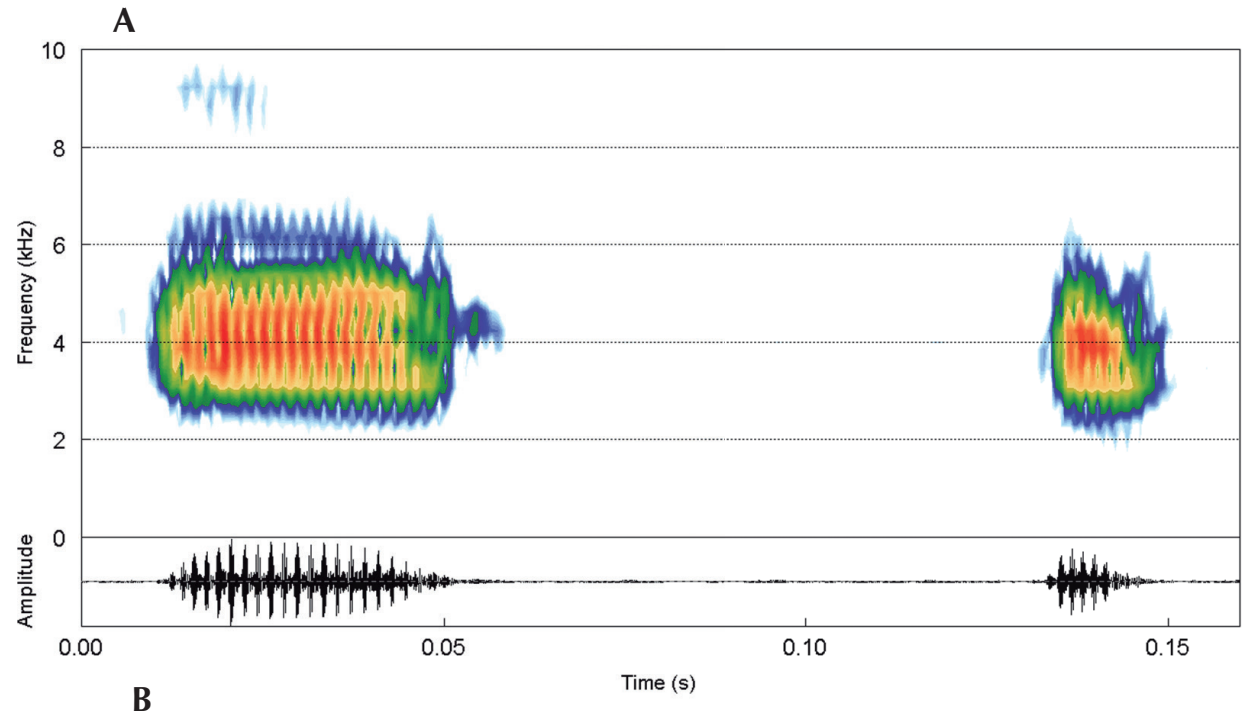

Amplitude

(dB)
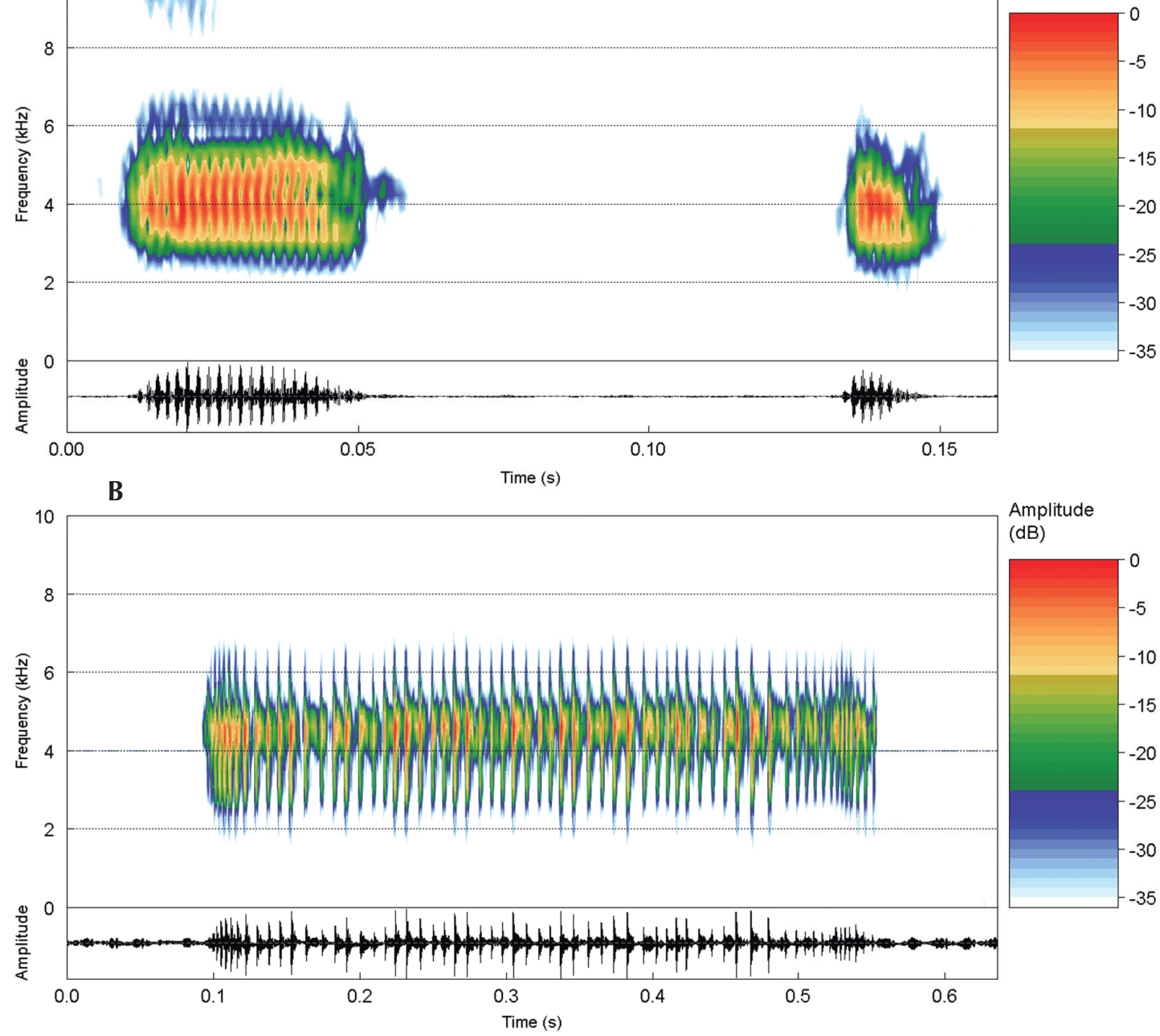

Amplitude

(dB)

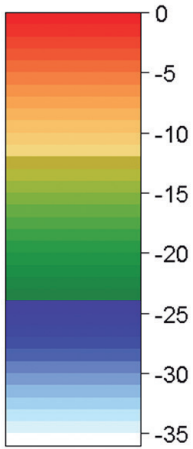

Figure 3. Variation in short and long call types (spectrograms and respective oscillograms). (A) Short calls emitted as a two-note series. Sound file: Scinax_cardosoiChiadorMG2LBM_AAGmt; recorded at 00:20 h, on 3 December 2011; air $16^{\circ} \mathrm{C}$, water $19^{\circ} \mathrm{C}$; (B) long call emitted as a single note. Sound file: Scinax cardosoiChiadorMG5LBM_AAGmt; recorded at 01:30 h, on 3 December 2011; air $16^{\circ} \mathrm{C}$, water $19^{\circ} \mathrm{C}$. Recorded in Chiador, Minas Gerais state, southeastern Brazil. 


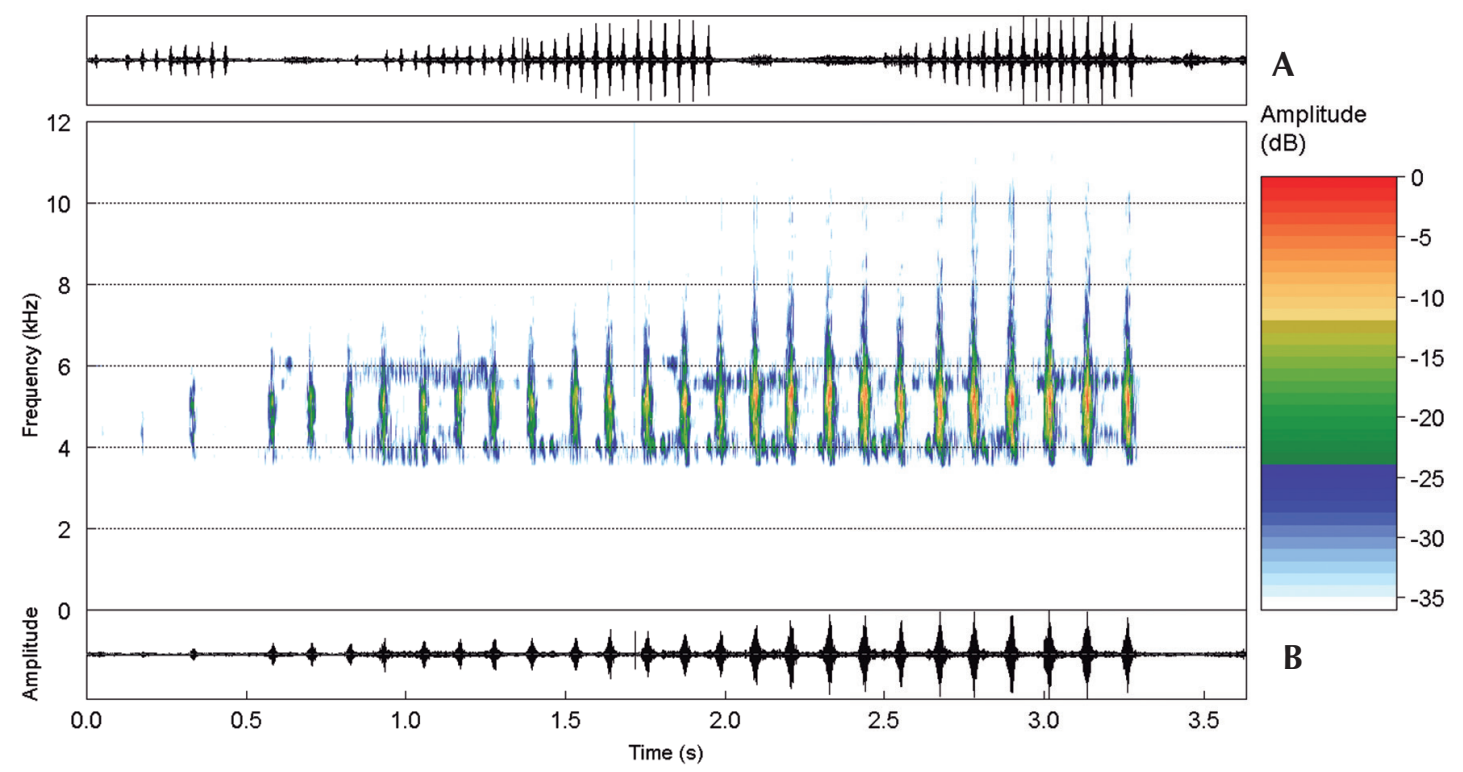

Figure 4. Waveform (A) of a series of three trilled calls (ca. 9 s); (B) spectrogram and respective oscillogram of the second call in A. Sound file: Scinax_cardosoiChiadorMG1LBM_AAGmt; recorded at 22:20 h, on 30 November 2011; air $20^{\circ} \mathrm{C}$, water $21^{\circ} \mathrm{C}$. Recorded in Chiador, Minas Gerais state, southeastern Brazil.

Table 1. Acoustic traits of Scinax cardosoi from Chiador, Minas Gerais state, southeastern Brazil. $N=$ number of recorded males (analyzed calls). Mean \pm SD (min-max).

\begin{tabular}{|c|c|c|c|}
\hline & $\begin{array}{l}\text { Short call } \\
N=6(73)\end{array}$ & $\begin{array}{l}\text { Long call } \\
N=3(14)\end{array}$ & $\begin{array}{c}\text { Trilled call } \\
N=1\end{array}$ \\
\hline Call duration (ms) & $40.0 \pm 8.1(16-66)$ & $427.0 \pm 80.2(268-518)$ & $2043.7 \pm 929.3(1100-2958)$ \\
\hline Call interval (s) & $5.8 \pm 4.6(0.5-11.9)$ & - & - \\
\hline Notes/call & $1.1 \pm 0.1(1-2)$ & $3.7 \pm 1.3(1-6)$ & $17.7 \pm 8.1(9-25)$ \\
\hline Note rate/s & - & - & $8.6 \pm 0.5(8.2-9.2)$ \\
\hline Pulses per call & $20.6 \pm 2.9(8-28)$ & $52.7 \pm 12.6(31-68)$ & - \\
\hline Pulse rate/s & $525.1 \pm 90.8(340.0-678.6)$ & $124.4 \pm 9.7(78.5-147.6)$ & - \\
\hline Call rate/min & $17.0 \pm 20.1(3.1-57.1)$ & $15.5 \pm 19.0(2.0-37.2)$ & - \\
\hline Dominant frequency $(\mathrm{Hz})$ & $4429.1 \pm 91.9(3281-4828)$ & $4386.1 \pm 34.1(4266-4500)$ & $5125.0 \pm 71.6(5063-5203)$ \\
\hline Air temperature $\left({ }^{\circ} \mathrm{C}\right)$ & & 16.0-20.0 & \\
\hline Water temperature $\left({ }^{\circ} \mathrm{C}\right)$ & & $19.0-21.0$ & \\
\hline
\end{tabular}


rates intermingled with short calls, which was the most frequent call type emitted among the recordings.

Trilled calls (Figure 4) were emitted by only one male ( $N=3$ calls) and have the lowest amplitude of all three call types; the call resembles an insect chirp, and consists of a long (call duration $>1 \mathrm{~s}$ ) pulsed-note series. The duration of the trilled call varies from 1100 $2958 \mathrm{~ms}$ (mean $=2043.7, \mathrm{SD}=929.3)$; the call is composed of 9-25 notes (mean $=17.7, \mathrm{SD}=$ 8.1), and is emitted at rates varying from 8.2-9.2 notes/s (mean $=8.6, \mathrm{SD}=0.5)$. The dominant frequency varies from $5063-5203 \mathrm{~Hz}$ (mean = 5125.0, $\mathrm{SD}=71.6$ ).

\section{Discussion}

The advertisement calls of members of the Scinax ruber Clade often are described as a single type of pulsed note. The vocalizations of $S$. cardosoi do not coincide closely with this pattern because they are composed of different call types that may be functionally significant in reproductive and aggressive activities. Such a distinctive vocal repertoire with variable emission patterns aids in the distinction of $S$. cardosoi from its congeners of the S. ruber Clade.

The trilled call of Scinax cardosoi (apparently the major advertisement signal) matches the long call (call duration $>350 \mathrm{~ms}$ ) category of Bilate and Lack (2011); this call type differentiates $S$. cardosoi from its congeners that are unassigned to a species group in the $S$. ruber Clade because its duration (1100-2958 ms) is longer than those species having short calls (combined range values: 70-340 ms): $S$. auratus (Nunes et al. 2007), S. blairi (Fouquette and Pyburn 1972), S. caldarum (Magrini and Giaretta 2010), S. castroviejoi (De la Riva et al. 1994), $S$. chiquitanus (De la Riva et al. 1994), S. cretatus (Nunes and Pombal Jr. 2011), S. cuspidatus (Pombal Jr. et al. 1995a), S. danae (Duellman 1986), S. elaeochrous (Duellman and Pyles 1983), S. eurydice (Pombal Jr. et al. 1995a), S. fuscovarius (Pombal Jr. et al. 1995a), S. granulatus (Conte et al. 2010), S. hayii (Pombal Jr. et al. 1995a), S. ictericus (Duellman and Wiens 1993), S. juncae (Nunes and Pombal Jr. 2010), $S$. lindsayi (Pyburn 1992), S. manriquei (BarrioAmorós et al. 2004), S. maracaya (Cardoso and Sazima 1980), S. nasicus (De la Riva et al. 1994), S. oreites (Duellman and Wiens 1993), $S$. pachycrus (Carneiro et al. 2004), S. perereca (Pombal Jr. et al. 1995b), S. quinquefasciatus (Duellman 1971), S. ruber (Duellman and Pyles 1983), S. similis (Bilate and Lack 2011), and $S$. tigrinus (Nunes et al. 2010).

Scinax cardosoi has a longer call duration (1100-2958 ms) than other species with long calls ( $\geq 350 \mathrm{~ms}$ ), as follow: S. crospedospilus (250-445 ms; Magrini et al. 2011), S. duartei (420-680 ms; Magrini et al. 2011), and S. wandae (442-710 ms; Pombal et al. 2011). It has a higher dominant frequency (5063-5203 $\mathrm{Hz}$ ) than S. acuminatus $(830-1560 \mathrm{~Hz}$; Magrini et al. 2011), S. alter (1300-4600 Hz; Pombal Jr. et al. 1995a), S. boesemani (1289-1529 Hz; Duellman and Pyles 1983), S. cabralensis (3700-4220 Hz; Drummond et al. 2007), S. curicica (2440-3660 Hz; Pugliese et al. 2004), S. exiguus (4000-4800; Duellman 1986), S. fuscomarginatus (2960-4594 Hz; Brusquetti et al. 2014), S. imbegue $(1200-5000 \mathrm{~Hz}$; as $S$. altera in Pombal Jr. et al. 1995a), S. madeirae (3369-3879 Hz; Brusquetti et al. 2014), S. rogerioi (1380-3190 Hz; Pugliese et al. 2009), S. rupestris (2067-2239 Hz; Araujo-Vieira et al. 2015), S. squalirostris (4048-4392 Hz; Pombal et al. 2011), and S. tymbamirim (4000-4300 Hz; Nunes et al. 2012).

Acoustic data, therefore, are taxonomically informative in the Scinax ruber Clade and provide additional characters that supplement the diagnosis in the original description of $S$. cardosoi by Carvalho-e-Silva and Peixoto (1991). Moreover, the vocalizations of $S$. cardosoi (squeaks-short calls, giggles-long calls, and insect chirps-trilled calls) are more similar to the complex vocal repertoires (multiple call types emitted in quite variable combinations) of 
species of the $S$. catharinae Clade (e.g., $S$. aromothyella, S. berthae, and S. rizibilis; Bastos and Haddad 2002, Pereyra et al. 2012), than they are to some species of the $S$. ruber Clade. The vocal repertories of the latter tend to have simpler call structures (a single type of multipulsed note emitted regularly; Pombal Jr. et al. 1995a, Bilate and Lack 2011).

The behavioral functions of the various calls of Scinax cardosoi must be addressed by studies in an experimental framework to identify on the specific context of each call type described in this study. It is possible that this array of call types and variable emission patterns (phrases) operate in more than one behavioral context (i.e., reproductive and aggressive behaviors).

\section{Acknowledgments}

This study was supported by $\mathrm{CNPq}$ and FAPEMIG. A research grant was awarded to AAG by CNPq. Doctoral fellowships were awarded by FAPESP to TRC and by CNPq to LBM. We thank two anonymous reviewers, Ignacio De la Riva, Jaime Bertoluci, and Linda Trueb for the comments and suggestions made in earlier versions of this study.

\section{References}

Araujo-Vieira, K., R. A. Brandão, and D. C. C. Faria. 2015. A new species of rock-dwelling Scinax Wagler (Anura: Hylidae) from Chapada dos Veadeiros, Central Brazil. Zootaxa 3915: 52-66.

Barrio-Amorós, C. L., A. Orellana, and A. Chacón. 2004. A new species of Scinax (Anura: Hylidae) from the Andes of Venezuela. Journal of Herpetology 38: 105-112.

Bastos, R. P. and C. F. B. Haddad. 2002. Acoustic and aggressive interactions in Scinax rizibilis (Anura: Hylidae) during the reproductive activity in southeastern Brazil. Amphibia-Reptilia 23: 97-104.

Bilate, M. and E. Lack. 2011. The advertisement call of Scinax similis (Cochran, 1952) (Amphibia, Anura). South American Journal of Herpetology 6: 54-58.

Bioacoustics Research Program. 2012. Raven Pro: Interactive Sound Analysis Software. Version 1.5. URL: http:// www.birds.cornell.edu/brp/raven/RavenOverview.html
Brusquetti, F., M. Jansen, C. Barrio-Amorós, M. Segalla, and C. F. B. Haddad. 2014. Taxonomic review of Scinax fuscomarginatus (Lutz, 1925) and related species (Anura; Hylidae). Zoological Journal of the Linnean Society 171: 783-821.

Cardoso, A. J. and I. Sazima. 1980. Nova espécie de Hyla do sudeste brasileiro (Amphibia, Anura, Hylidae). Revista Brasileira de Biologia 40: 75-79.

Carneiro, M. C. L., P. S. Magalhães, and F. A. Juncá. 2004. Descrição do girino e vocalização de Scinax pachycrus (Miranda-Ribeiro, 1937) (Amphibia, Anura, Hylidae). Arquivos do Museu Nacional, Rio de Janeiro 62: 241246.

Carvalho, T. R. and A. A. Giaretta. 2013. Taxonomic circumscription of Adenomera martinezi (Bokermann, 1956) (Anura: Leptodactylidae: Leptodactylinae) with the recognition of a new cryptic taxon through a bioacoustic approach. Zootaxa 3701: 207-237.

Carvalho, T. R., L. B. Martins, B. F. V. Teixeira, L. B. Godinho, and A. A. Giaretta. 2015. Intraspecific variation in acoustic traits and body size, and new distributional records for Pseudopaludicola giarettai Carvalho, 2012 (Anura, Leptodactylidae, Leiuperinae): implications for its congeneric diagnosis. Papéis Avulsos de Zoologia 55: 245-254.

Carvalho-e-Silva, S. P. and O. L. Peixoto. 1991. Duas novas espécies de Ololygon para os estados do Rio de Janeiro e Espírito Santo (Amphibia, Anura, Hylidae). Revista Brasileira de Biologia 51: 263-270.

Cocroft, R. B. and M. J. Ryan. 1995. Patterns of advertisement call evolution in toads and chorus frogs. Animal Behaviour 49: 283-303.

Conte, C. E., F. Nomura, R. A. Machado, A. Kwet, R. Lingnau, and D. C. Rossa-Feres. 2010. Novos registros na distribuição geográfica de anuros na Floresta com Araucária e considerações sobre suas vocalizações. Biota Neotropica 10: 201-224.

De la Riva, I. 1993. A new species of Scinax (Anura, Hylidae) from Argentina and Bolivia. Journal of Herpetology 27: 41-46.

De la Riva, I., R. Márquez, and J. Bösch. 1994. Advertisement calls of Bolivian species of Scinax (Amphibia, Anura, Hylidae). Bijdragen tot de Dierkunde 64: 75-85.

Drummond, L. O., D. Baêta, and M. R. S. Pires. 2007. A new species of Scinax (Anura, Hylidae) of the S. ruber clade from Minas Gerais, Brazil. Zootaxa 1612: 45-53.

Duellman, W. E. (ed.). 1970. The Hylid Frogs of Middle America. Lawrence. The University of Kansas Press. $473 \mathrm{pp}$. 
Duellman, W. E. 1971. The identities of some Ecuatorian hylid frogs. Herpetologica 27: 212-227.

Duellman, W. E. 1986. Two new species of Ololygon (Anura: Hylidae) from the Venezuelan Guyana. Copeia 1986: 864-870.

Duellman, W. E. and R. A. Pyles. 1983. Acoustic resource partitioning in anuran communities. Copeia 1983: 639649.

Duellman, W. E. and J. J. Wiens. 1993. Hylid frogs of the genus Scinax Wagler, 1830, in Amazonian Ecuador and Peru. Occasional Papers of the Museum of Natural History 153: 1-57.

Faivovich, J. 2002. A cladistics analysis of Scinax (Anura: Hylidae). Cladistics 18: 367-393.

Faivovich, J., C. F. B. Haddad, P. C. A. Garcia, D. R. Frost, J. A. Campbell, and W. C. Wheeler. 2005. Systematic review of the frog family Hylidae, with special reference to Hylinae: phylogenetic analysis and taxonomic revision. Bulletin of the American Museum Natural History 294: 1-240.

Fouquette, M. J., Jr. and W. F. Pyburn. 1972. A new Colombian treefrog of the Hyla rubra complex. Herpetologica 28: 176-181.

Frost, D. R. (ed.). 2015. Amphibian Species of the World: an Online Reference. Version 6.0. Electronic Database accessible at http://research.amnh.org/vz/herpetology/ amphibia/index.php American Museum of Natural History, New York, USA. Captured on 19 March 2015.

Gerhardt, H. C. 1994. The evolution of vocalization in frogs and toads. Annual Review of Ecology, Evolution, and Systematics 25: 293-324.

Heyer, W. R., J. M. García-Lopez, and A. J. Cardoso. 1996. Advertisement call variation in the Leptodactylus mystaceus species complex (Amphibia: Leptodactylidae) with a description of a new sibling species. AmphibiaReptilia 17: 7-31.

Linares, A. M., M. H. O. Batemarque, H. E. S. Mello, and L. B. Nascimento. 2011. Amphibia, Anura, Hylidae, Scinax cardosoi (Carvalho-e-Silva and Peixoto, 1991): Distribution extension. Check List 7: 407-408.

Magrini, L. and A. A. Giaretta. 2010. Calls of two Brazilian species of Scinax of the S. ruber clade (Anura: Hylidae). Herpetology Notes 3: 121-126.

Magrini, L., S. P. Carvalho-e-Silva, A. F. Béda, and A. A. Giaretta. 2011. Calls of five species of Scinax ruber (Anura: Hylidae) clade from Brazil with comments on their taxonomy. Zootaxa 3066: 37-51.
Narins, P. M. and R. P. Capranica. 1978. Communicative significance of the two-note call of the treefrog Eleutherodactylus coqui. Journal of Comparative Physiology 127: 1-9.

Nunes, I., R. S. Santiago, and F. A. Juncá. 2007. Advertisement calls of four hylid frogs from the state of Bahia, northeastern Brazil (Amphibia, Anura, Hylidae). South American Journal of Herpetology 2: 89-96.

Nunes, I. and, J. P. Pombal Jr. 2010. A new Scinax Wagler (Amphibia, Anura, Hylidae) from the Atlantic Forest remains of southern State of Bahia, North-eastern Brazil. Amphibia-Reptilia 31: 347-353.

Nunes, I., R. R. Carvalho Jr., and E. G. Pereira. 2010. A new species of Scinax Wagler (Anura: Hylidae) from Cerrado of Brazil. Zootaxa 2514: 24-34.

Nunes, I. and J. P. Pombal Jr. 2011. A new snouted treefrog of the speciose genus Scinax Wagler (Anura, Hylidae) from Northeastern Brazil. Herpetologica 67: 80-88.

Nunes, I., A. Kwet, and J. P. Pombal Jr. 2012. Taxonomic revision of the Scinax alter species complex (Anura: Hylidae). Copeia 2012: 554-569.

Obrist, M. K., G. Pavan, J. Sueur, K. Riede, D. Llusia, and R. Márquez. 2010. Bioacoustics approaches in biodiversity inventories. Pp. 68-99 in J. Eymann, J. Degreef, C. L. Häuser, J. C. Monje, Y. Samyn, and D. VandenSpiegel (eds.), Manual on field recording techniques and protocols for all taxa biodiversity inventories and monitoring. Abc Taxa 8: 1-653.

Padial, J. M., J. Köhler, A. Muñoz, and I. De la Riva. 2008. Assessing the taxonomic status of tropical frogs through bioacoustics: geographical variation in the advertisement calls in the Eleutherodactylus discoidalis species group (Anura). Zoologial Journal of the Linnean Society 152: 353-365.

Pereyra, M. O., C. Borteiro, D. Baldo, F. Kolenc, and C. E. Conte. 2012. Advertisement call of the closely related species Scinax aromothyella Faivovich 2005 and S. berthae (Barrio 1962), with comments on the complex calls in the S. catharinae group. Herpetological Journal 22: $133-137$.

Pinto, F. C. S., R. A. R. Campos, F. S. Braga, F. N. S. Queirós, and L. B. Nascimento. 2009. Amphibia, Anura, Hylidae, Scinax cardosoi Carvalho-e-Silva and Peixoto, 1991: Distribution extension and new state records. Check List 5: 866-868.

Pombal Jr., J. P., R. P. Bastos, and C. F. B. Haddad. 1995a. Vocalizações de algumas espécies do gênero Scinax (Anura, Hylidae) do sudeste do Brasil e comentários taxonômicos. Naturalia, São Paulo 20: 213-225. 
Pombal Jr., J. P., C. F. B. Haddad, and S. Kasahara. 1995b. A new species of Scinax (Anura: Hylidae) from Southeastern Brazil, with comments on the genus. Journal of Herpetology 29: 1-6.

Pombal, Jr., J. P., M. Bilate, P. G. Gambale, L. Signorelli, and R. P. Bastos. 2011. A new miniature treefrog of the Scinax ruber clade from the Cerrado of central Brazil (Anura: Hylidae). Herpetologica 67: 288-299.

Pugliese, A., J. P. Pombal Jr., and I. Sazima. 2004. A new species of Scinax (Anura: Hylidae) from rocky montane fields of the Serra do Cipó, Southeastern Brazil. Zootaxa 688: $1-15$.

Pugliese A., D. Baêta, and J. P. Pombal Jr. 2009. A new species of Scinax from rocky montane fields in southeastern and central Brazil. Zootaxa 2269: 53-64.

Pyburn, W. F. 1992. A new tree frog of the genus Scinax from the Vaupés River of northwestern Brazil. Texas Journal of Science 44: 405-411.
R Core Team. 2014. R Foundation for Statistical Computing. Version 3.1.0. URL: http://www.R-project.org (accessed on 19 March 2015).

Robillard, T., G. Höbel, and H. C. Gerhardt. 2006. Evolution of advertisement signals in North American hylid frogs: vocalizations as end-products of calling behavior. Cladistics 22: 533-545.

Sueur, J., T. Aubin, and C. Simonis. 2008. Seewave, a free modular tool for sound analysis and synthesis. Bioacoustics 18: 213-226.

Toledo, L. F., I. A. Martins, D. P. Bruschi, M. A. Passos, C. Alexandre, and C. F. B. Haddad. 2015. The anuran calling repertoire in the light of social context. Acta Ethologica 18: 87-99.

Wells, K. D. (ed.). 2007. The Ecology and Behavior of Amphibians. Chicago. The University of Chicago Press. 1087 pp.

Editor: Ignacio De la Riva 